\title{
Oestrogen concentrations in systemic plasma of pregnant pygmy goats*
}

\author{
D. S. Dhindsa†, J. Metcalfe and J. A. Resko \\ Departments of Medicine and Physiology, University of Oregon Health Sciences Center, \\ Portland, Oregon 97201, and Reproductive Physiology, Oregon Regional Primate Center, \\ Beaverton, Oregon 97006, U.S.A.
}

\begin{abstract}
Summary. Concentrations of oestradiol-17 $\beta$, oestradiol-17 $\alpha$, and oestrone in systemic plasma of pregnant pygmy goats (Capra hircus) remained low until about Day 60 and then rose to maximum values at Days 120-140 (parturition Day 140-145). Oestradiol-17 $\alpha$ was the predominant oestrogen. All 3 oestrogens at Days 100-130 were higher in females carrying 3 fetuses than in those carrying only one, but at Days 70-90 only oestrone values were higher. It is suggested that the feto-placental unit is the source of oestrogens during gestation in goats.
\end{abstract}

\section{Introduction}

The pygmy goat is frequently used for physiological and pharmacological studies in pregnancy, and the reasons have been discussed elsewhere (Metcalfe, Hoversland, Erickson, Rogers \& Clary, 1968; Hoversland, Dhindsa \& Metcalfe, 1971). Various workers have reported oestrogen concentrations in goat plasma in late pregnancy and at parturition (Thorburn, Nicol, Bassett, Shutt \& Cox, 1972; Currie, Wong, Cox \& Thorburn, 1973; Umo, Fitzpatrick \& Ward, 1976; Flint, Kingston, Robinson \& Thorburn, 1978). Although Challis \& Linzell (1971) described total unconjugated oestrogens at various stages of pregnancy in the goat, little is known about individual oestrogen concentrations at these stages. In an effort to obtain more basic knowledge about fluctuations in oestrogens during pregnancy in this species, we have measured the quantities of oestrone, oestradiol-17 , and oestradiol-17 $\alpha$ circulating in systemic plasma.

\section{Materials and Methods}

Six pygmy goats (Capra hircus) used in this study were mated at a spontaneous oestrus or at oestrus induced by Cronolone (9-fluoro-11ß,17-dihydroxyprogesterone-17, acetate) treatment (Dhindsa, Hoversland \& Metcalfe, 1971). Blood samples (4 ml) were taken from the jugular veins of unanaesthetized animals into heparinized syringes at about 10 -day intervals during pregnancy. Blood samples were centrifuged immediately, and the plasma was removed and frozen at $-16^{\circ} \mathrm{C}$ until steroid analyses were performed. Concentrations of oestrone, oestradiol- $17 \beta$ and oestradiol-17 $\alpha$ were measured by radioimmunoassay. The steroids (free and conjugated to plasma proteins) were extracted with ether from $250 \mu \mathrm{l}$ goat plasma, and were U.S.A.

* Reprint requests to Dr J. A. Resko, Oregon Regional Primate Research Center, Beaverton, Oregon 97006,

† Present address: Reproductive Biology Study Section, Division of Research Grants, National Institutes of Health, Room 307, Westwood Building, Bethesda, Maryland 20205, U.S.A. 
separated on Sephadex LH-20 columns in the solvent system hexane:benzene:methanol $(62: 20: 13$ by vol.). The dimensions of the columns and the fractions analysed have been reported elsewhere (Resko, Ploem \& Stadelman, 1975). The specificity of the antisera and estimates of assay reliability are presented in Table 1 .

Table 1. Specificity and reliability of oestrogen measurements with radioimmunoassay after chromatography on Sephadex LH-20

\begin{tabular}{|c|c|c|c|c|c|c|}
\hline \multirow[b]{2}{*}{ Steroid tested } & \multicolumn{2}{|c|}{$\%$ Cross-reactivity* } & \multirow{2}{*}{$\begin{array}{l}\text { Eluant volume } \\
(\mathrm{ml})\end{array}$} & \multirow{2}{*}{$\begin{array}{c}\% \\
\text { Recovery }\end{array}$} & \multirow{2}{*}{$\begin{array}{l}\text { Water blank } \\
(\mathrm{pg} / \mathrm{ml})\end{array}$} & \multirow{2}{*}{$\begin{array}{l}\text { Within-assay } \\
\text { coefficient of } \\
\text { variation }\end{array}$} \\
\hline & Antiserum $\mathrm{A}^{\dagger}$ & Antiserum B $\ddagger$ & & & & \\
\hline Oestrone & $100 \cdot 00$ & 0.09 & $7-9$ & $\begin{array}{c}83 \cdot 9 \pm 2 \cdot 0 \\
(10)\end{array}$ & $\begin{array}{c}2 \cdot 4 \pm 0 \cdot 6 \\
(10)\end{array}$ & $\begin{array}{c}9 \cdot 8 \% \\
(9)\end{array}$ \\
\hline Oestradiol-17 $\alpha$ & $124 \cdot 30$ & 0.06 & $10-15$ & -9 & $3 \cdot 7 \pm 1 \cdot 6$ & $\begin{array}{l}8 \cdot 8 \% \\
(10)\end{array}$ \\
\hline Oestradiol-17 $\beta$ & $389 \cdot 60$ & $100 \cdot 00$ & $11-15$ & $\begin{array}{c}79.97 \pm 1.83 \\
(10)\end{array}$ & $\begin{array}{c}1 \cdot 0 \pm 0 \cdot 2 \\
(10)\end{array}$ & $\begin{array}{c}10.2 \% \\
(9)\end{array}$ \\
\hline Oestriol & $16 \cdot 20$ & 0.09 & $>20$ & - & - & - \\
\hline
\end{tabular}

Values are mean \pm s.e.m. for the number of samples indicated in parentheses. The sensitivity of these assays is at least $5 \mathrm{pg} /$ tube since measurements of $5 \mathrm{pg}$ quantities are significantly different from steroid-free serum blanks $(P<0.05)$.

* Little or no cross-reactivity (with $500 \mathrm{pg}$ oestrone or oestradiol) was found when 20 neutral steroids (androgens, progestagens and corticoids) were tested with both antisera.

$\dagger$ Antiserum obtained from a sheep immunized with oestradiol-17 $\beta$-succinyl-bovine serum albumin (BSA). The percentage was calculated with $500 \mathrm{pg}$ oestrone as the reference $(100 \%)$.

$\ddagger$ Antiserum obtained from a rabbit immunized with 6 -keto-oestradiol-17 $\beta$ coupled to BSA. The percentage was calculated with $500 \mathrm{pg}$ oestradiol as the reference (100\%).

$\S$ All samples were analysed in the same assay.

T Recoveries of oestradiol-17 $\beta$ used for oestradiol-17 $\alpha$.

We used Antiserum A to measure oestrone and oestradiol-17 $\alpha$ and Antiserum B to quantify oestradiol-17 $\beta$. Approximately $6 \%$ of the oestradiol-17 $\alpha$ may be removed and quantified as oestrone when oestrone is isolated on Sephadex LH-20 columns. Since oestradiol-17 $\alpha$ and $-17 \beta$ do not separate on our chromatography system (see Table 1), we differentiated the isomers by collecting the oestradiol fraction from the column, dividing it into two parts and assaying each part with Antiserum A or B. Oestradiol-17 $\alpha$ does not cross-react with Antiserum B used to quantify oestradiol- $17 \beta$ and our estimates of oestradiol-17\% are therefore reliable. The oestradiol-17 $\alpha$ measurements, however, may have been elevated slightly by the small quantities of oestradiol-17 $\beta$ in the serum samples since Antiserum A also cross-reacts with oestradiol-17 $\beta$. However, the concentrations of oestradiol-17 $\beta$ were so small relative to those of oestradiol-17 $\alpha$ that they did not significantly affect the measurements. This fact became evident when different aliquots of the oestradiol-17 $\alpha$ extracted from plasma of several goats were assayed and compared with a standard solution of oestradiol-17 $\alpha$ : different volumes of material extracted from goat plasma gave results parallel to those obtained with different concentrations of oestradiol-17 $\alpha$ in our radioimmunoassay. Oestradiol-17 $\alpha$ and oestradiol-17 $\beta$ standards are not parallel to each other under these test conditions.

Statistical comparisons were made by means of Student's $t$ tests. The influence of the number of fetuses on oestrogen concentrations in the maternal circulation was estimated by the MannWhitney U test.

\section{Results}

\section{Oestrone}

The concentrations of oestrone in the peripheral plasma of 6 pregnant goats are shown in 
Text-fig. 1a. From Days 10 to 30 of gestation oestrone levels remained low. Beginning on Day 40 , oestrone levels rose significantly $(t=3.5111,11$ d.f., $P<0.01)$ and reached their highest value, $450 \pm 60$ (s.e.m.) $\mathrm{ng} / \mathrm{ml}$, on Day 120 of pregnancy. Oestrone levels then declined slightly but not significantly.

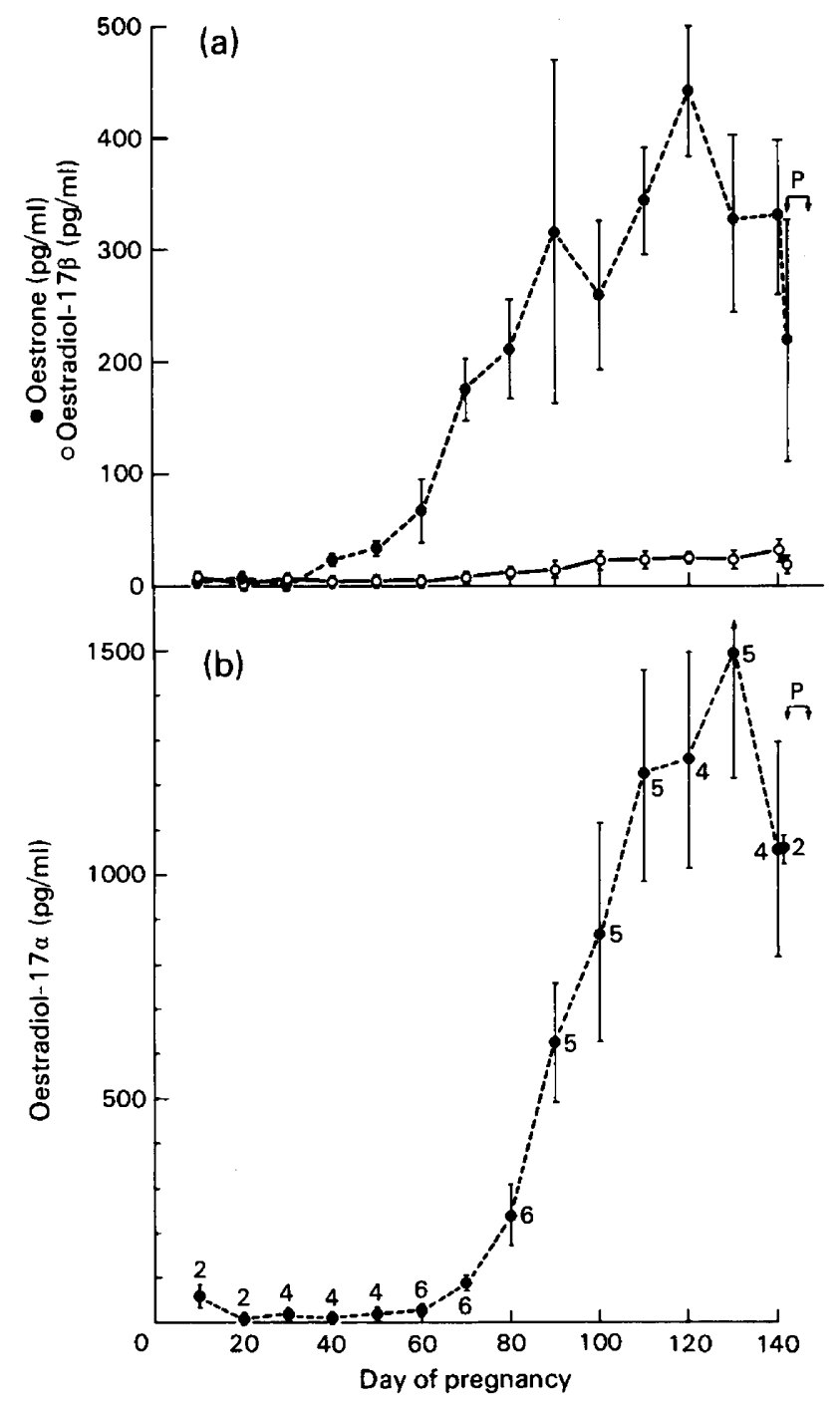

Text-fig. 1. Concentrations of (a) oestrone (O) and oestradiol-17 $\beta(O)$ and (b) oestradiol-17a in the systemic plasma of pregnant pygmy goats. Values are mean \pm s.e.m. for 6 animals in (a) and the numbers indicated in (b). $\mathrm{P}=$ range for parturition.

\section{Oestradiol-17 $\beta$}

Concentrations were quite low from Day 10 to Day 60 of gestation (Text-fig. 1a) but then rose steadily to reach the highest value, $32 \pm 9$ (s.e.m.) $\mathrm{pg} / \mathrm{ml}$, on Day 140 , and then declined before parturition. The first significant elevation in oestradiol-17 $\beta$ levels above the basal level occurred on Day $60(t=2.8985,13$ d.f., $P<0.02)$. 


\section{Oestradiol-17a}

Values were low from Days 10 to 60 of gestation (Text-fig. 1b) but then increased steadily and reached a peak value of $1.5 \pm 0.3$ (s.e.m.) $\mathrm{ng} / \mathrm{ml}$ on Day 130 . There was a decline to $1.1 \pm$ 0.2 (s.e.m.) $\mathrm{ng} / \mathrm{ml}$ plasma on Day 140 , but this was not significant because of the large variation between samples.

\section{Fetal number and steroid concentrations}

To determine whether the number of fetuses affected steroid concentrations in the maternal blood, the data relating to oestrone and oestradiol were divided into two groups, one containing values for Days 70-90 and the other values for Days 100-130 of gestation (Table 2).

Table 2. Oestrogen concentrations in the maternal circulation of pygmy goats in relation to the number of fetuses

\begin{tabular}{|c|c|c|c|c|c|}
\hline \multirow{2}{*}{$\begin{array}{c}\text { Gestational age } \\
\text { (days) }\end{array}$} & \multirow{2}{*}{$\begin{array}{l}\text { No. of } \\
\text { fetuses }\end{array}$} & \multirow{2}{*}{$\begin{array}{l}\text { No. of } \\
\text { pregnant } \\
\text { females }\end{array}$} & \multicolumn{3}{|c|}{ Oestrogen conc. $(\mathrm{pg} / \mathrm{ml})$} \\
\hline & & & Oestrone & Oestradiol-17 $\beta$ & Oestradiol-17 $\alpha$ \\
\hline $70-90$ & 1 & 3 & $\begin{array}{c}140 \pm 20 \\
(10)\end{array}$ & $\begin{array}{r}9 \pm 2 \\
(8)\end{array}$ & $240 \underset{(8)}{ \pm} 70$ \\
\hline $70-90$ & 2 or 3 & 3 & $320 \pm \frac{\left(90^{*}\right.}{(9)}$ & $\begin{array}{r}16 \pm 2 \\
(8)\end{array}$ & $360 \pm \frac{120}{(9)}$ \\
\hline $100-130$ & 1 & 3 & $\begin{array}{c}290 \pm 20 \\
(12)\end{array}$ & $20 \pm 2$ & $\begin{array}{c}930 \pm 130 \\
(11)\end{array}$ \\
\hline $100-130$ & 3 & 2 & $\begin{array}{c}480 \pm 40^{*} \\
(12)\end{array}$ & $\begin{array}{c}34 \pm 3^{* *} \\
(8)\end{array}$ & $1670 \pm \frac{(8)}{ \pm}$ \\
\hline
\end{tabular}

\footnotetext{
Values are mean \pm s.e.m. for the number of samples indicated in parentheses.

Values differing significantly from those for goats carrying 1 fetus: ${ }^{*} P<0.05 ;{ }^{* *} P<0.005$ (Mann-Whitney U test).
}

Between Days 70 and 90 the oestrone levels in goats carrying single fetuses were significantly lower $(P<0.05)$ than those in goats carrying 2 or 3 fetuses $(140 \pm 20$ versus $320 \pm 80 \mathrm{ng} / \mathrm{ml})$. Similarly, goats carrying single fetuses between Days 100 and 130 of gestation had significantly lower $(P<0.002)$ levels of oestrone than did goats carrying triplets $(290 \pm 20$ versus $480 \pm 40$ $\mathrm{ng} / \mathrm{ml})$.

Between Days 70 and 90 of gestation, concentrations of oestradiol-17 $\beta$ and oestradiol-17 $\alpha$ in the peripheral plasma of pregnant goats were not significantly different $(P>0.05)$ in relation to the number of fetuses being carried. However, the levels of both isomers between Days 100 and 130 of gestation were significantly lower $(P<0.05)$ in goats carrying single fetuses than those carrying triplets.

\section{Discussion}

This study demonstrates changes in systemic concentrations of three physiological oestrogens throughout pregnancy in the pygmy goat, a breed of goat that is becoming popular for biological research.

Oestradiol-17 $\beta$ is produced in small quantities throughout pregnancy. The quantities of oestrone were much greater, and oestradiol-17 $\alpha$ was produced in the largest amounts. Our data agree with those reported by other investigators who used other methods of oestrogen measurement (Thorburn et al., 1972). We did not observe an elevation in oestrogen before parturition. Our data, however, were not collected close enough to the time of parturition to establish this point with any degree of certainty. The fact that levels of all three oestrogens were 
significantly higher in the plasma of pregnant animals with multiple fetuses than in the plasma of animals with only one fetus suggests a fetal-placental source of oestrogen in this species. This same conclusion was drawn by Thorburn et al. (1972) who compared oestrone and oestradiol-17 $\alpha$ concentrations in uterine venous and arterial plasma and after infusion of fetuses with synthetic ACTH.

The function of oestradiol-17 $\alpha$ in goats as the major oestrogen secreted during pregnancy is not understood. In fact, little is known about the biological activity of this oestrogen in the goat. Although oestradiol-17 $\alpha$ is thought to have weak oestrogenic activity, Huggins \& Jensen (1955) stimulated uterine growth with large amounts of this compound. Toft \& Gorski (1966) demonstrated partial binding of oestradiol-17 $\alpha$ to the cytoplasmic oestrogen receptor compared to oestradiol-17 $\beta$. However, these studies were performed in rats not in goats. Perhaps oestradiol $17 \alpha$ is more active in goats than other species. Alternatively, the large amounts secreted during pregnancy may represent a detoxification mechanism of the pregnant female to high levels of oestrogen secretion.

The work described in this article, Publication No. 1112 from the Oregon Regional Primate Research Center, was supported in part by U.S. Public Health Services Grants HL-14121, HL-14979, RR-00163, and HD-05969, and the Oregon Heart Association. We thank Henry Stadelman, Linda Horton, and Maralee Lawson for technical assistance.

\section{References}

Challis, J.R.G. \& Linzell, J.L. (1971) The concentrations of total unconjugated oestrogens in the plasma of pregnant goats. J. Reprod. Fert. 26, 401-404.

Currie, W.B., Wong, M.S.F., Cox, R.I. \& Thorburn, G.D. (1973) Spontaneous or dexamethasone-induced parturition in the sheep and goat: changes in plasma concentrations of maternal prostaglandin $F$ and foetal oestrogen sulphate. Mem. Soc. Endocrinol. 20, 95-118.

Dhindsa, D.S., Hoversland, A.S. \& Metcalfe, J. (1971) Reproductive performance in goats treated with progestogen impregnated sponges and gonadotrophins. J. Anim. Sci. 32, 301-306.

Flint, A.P.F., Kingston, E.J., Robinson, J.S. \& Thorburn, G.D. (1978) Initiation of parturition in the goat: evidence for control by foetal glucocorticoid through activation of placental $\mathrm{C}_{21}$-steroid $17 \alpha$-hydroxylase. J. Endocr. 78, 367-378.

Hoversland, A.S., Dhindsa, D.S. \& Metcalfe, J. (1971) The usefulness of the pygmy goat as a research animal. In 2nd International Conference about Goat-breeding, pp. 367-371. I.T.V.I.C., Paris.

Huggins, C. \& Jensen, E.V. (1955) The depression of estrone-induced uterine growth by phenolic estrogens with oxygenated functions at positions 6 or 16 : the impeded estrogens. J. exp. Med. 102, 335-346.

Metcalfe, J., Hoversland, A.S., Erickson, L.F., Rogers, A.L. \& Clary, P.L. (1968) The pygmy goat as an experimental animal. In Animal Models for Biomedical Research, pp. 55-63. Publication No. 15, National Academy of Sciences, Washington, D. C.

Resko, J.A., Ploem, J.G. \& Stadelman, H.L. (1975) Estrogens in fetal and maternal plasma of the rhesus monkey. Endocrinology 97, 425-430.

Thorburn, G.D., Nicol, D.H., Bassett, J.M., Shutt, D.A. \& Cox, R.I. (1972) Parturition in the goat and sheep: changes in corticosteroids, progesterone, oestrogens and prostaglandin F. J. Reprod. Fert., Suppl. 16, 61-84.

Toft, D. \& Gorski, J. (1966) A receptor molecule for estrogens: isolation from the rat uterus and preliminary characterization. Proc. natn. Acad. Sci. U.S.A. 55, 1574-1581.

Umo, I., Fitzpatrick, R.J. \& Ward, W.R. (1976) Parturition in the goat: plasma concentrations of prostaglandin $\mathrm{F}$ and steroid hormones and uterine activity during later pregnancy and parturition. $J$. Endocr. 68, 383-389. 